\title{
АНАЛІЗ ВПЛИВУ ЗОВНІШНІХ ТА ВНУТРІШНІХ ФАКТОРІВ НА ПРОЦЕС ВПРОВАДЖЕННЯ МАРКЕТИНГОВОГО ТЕСТУВАННЯ ІННОВАЦІЙНОЇ ПРОДУКЦІї 1
}

\author{
Голишева Євгенія Олексіївна \\ кандидат економічних наук, доцент \\ Сумський національний аграрний університет (м.Суми, Україна) \\ ORCID: 0000-0001-7788-9897 \\ ievgeniia.golysheva@snau.edu.ua
}

У статті проаналізовано місце та показники України в рейтингах різних сфрер: інноваційної, інформаційної та державного управління. Незалежне оцінювання міжнародних організацій дозволило виділити сильні та слабкі сторони украйнської економіки. На основні цього були визначенні проблеми, які можуть виникати на вітчизняних підприємствах в процесі впровадження маркетингового тестування інноваційної продукиії.

Ключові слова: інновація, інформатизація, корупція, інноваційний цикл.

DOI: https://doi.org/10.32845/bsnau.2019.2.1

Вступ. У сучасних умовах мінливого зовнішнього середовища підприємства постійно перебувають у пошуках нових шляхів розвитку та підвищення конкурентоспроможності свого бізнесу. Однією із можливістю випередити конкурентів та зацікавити споживачів $є$ орієнтація на інновації. Інфрормаційне суспільство та науково-технологічний процес сьогодення сприяють створенню нових продуктів, появі нових технологій, реорганізацію бізнес-процесів відповідно до викликів сучасних тенденцій. Разом з тим інноваційна діяльність пов'язана зі значної кількістю ризиків, лише невеликий відсоток інноваційних розробок стають у результаті успішними товарами на ринку. У таких умовах підвищується значення маркетингового тестування, яке допомагає визначити проблемні аспекти розроблення та впровадження інновацій, а також вчасно їх виправити.

Аналіз останніх досліджень і публікацій. Нагорний Є.І. (2013) визначає маркетингове тестування з двох сторін: технічної та маркетингової. Так, з технічної точки зору тестування - це дослідження відповідності виробу технічним та функціональним вимогам, експериментальна оцінка його параметрів, а також оцінка наявності в ньому дефектів; а з маркетингової - дослідження адекватності виробу та його атрибутів, а також маркетингової стратегії ринковим умовам. Також зазначено, що маркетингове тестування потрібно проводити в продовж всього циклу розроблення інноваційної продукції, а не тільки перед безпосереднім виходом на ринок уже готового продукту. Це дозволить підвищити успішність інновації на ринку та уникнути помилок та зайвих витрат підприємства.

Проте підприємство в процесі впровадження маркетингового тестування інноваційної продукції може стикнутися з рядом проблем. Тому метою статті $€$ аналіз показників інноваційної діяльності в Україні на основі оцінки незалежних міжнародних установ для визначення основних проблем впровадження маркетингового тестування інноваційної продукції на вітчизняних підприємствах.

\section{Основний матеріал.}

Для початку розглянемо місце України в різних рейтингах, які пов'язані з інноваційною та інформаційною діяльністю.

Глобальний інноваційний індекс (The Global Innovation Index (GII)) - це проект, який створений спільно Корнельським університетом, школою бізнесу INSEAD і Всесвітньою організацією інтелектуальної власності (BОIВ). ГІІ складається з двох субіндексів: вхідного та вихідного. До вхідного субіндексу включені такі елементи національної економіки, які забезпечують інноваційну діяльність: інститути, людський капітал і дослідження, інфраструктура, витонченість ринку та бізнесу. Елементи вихідного субіндексу відображають фрактичні результати інновацій: результати знань і технологій та творчі результати.

Кожен елемент розділений на допоміжні компоненти, а кожен допоміжний компонент складається з окремих показників (всього 80 в 2018 році). Підрахунок балів здійснюється як середньозважене значення окремих показників. Загальна оцінка ГІІ є середнім з 2 субіндексів.

У 2018 році Україна посіла 43 місце серед 126 країн, при цьому найгірші показники країна має в елементі «Інститути» (107 місце): слабкими сторонами країни $€$ його політичне оточення (122 місце), яке включає політичну стабільність та безпеку (123 місце) та ефективність уряду (102 місце). Також необхідно відзначити складну процедуру признання підприємства банкрутом (118 місце). Система показників із відповідними балами наведена в табл. 1.

\footnotetext{
${ }^{1}$ Робота виконана за рахунок бюджетних коштів МОН України, наданих на виконання науково-дослідної теми «Розробка науково-методичних засад та практичного інструментарію оцінювання комерційних (ринкових) перспектив товарних інновацій» (№ ДР 0119U100179)
} 
Таблиця 1 - Складові показника «Інститути» України Глобального індексу інновацій у 2018 році

\begin{tabular}{|l|r|r|}
\hline \multicolumn{1}{|c|}{ Показник } & \multicolumn{1}{c|}{ Оцінка } & \multicolumn{1}{c|}{ Місце } \\
\hline 1.1. Політичне середовище & $\mathbf{2 7 , 4}$ & $\mathbf{1 2 2}$ \\
\hline 1.1.1. Політична стабільність та безпека & 20,9 & 123 \\
\hline 1.1.2 Ефективність уряду & 30,7 & 102 \\
\hline 1.2. Регуляторне середовище & $\mathbf{6 0 , 2}$ & $\mathbf{7 8}$ \\
\hline 1.2.1. Якість регулювання & 33,1 & 97 \\
\hline 1.2.2. Верховенство права & 22,9 & 107 \\
\hline 1.2.3. Вартість звільнення з посади, тижнева заробітна плата & 13,0 & 43 \\
\hline 1.3. Бізнес-середовише & $\mathbf{5 9 , 6}$ & $\mathbf{1 0 0}$ \\
\hline 1.3.1. Легкість відкриття бізнесу & 91,1 & 45 \\
\hline 1.3.2. Легкість вирішення банкрутства & 28,2 & 118 \\
\hline Джерело: побудовано на основі даних Глобального інноваційного індексу (2018) &
\end{tabular}

Найсильнішою стороною України в GII став показник «Результати знань та технологій», за яким Україна посіла 27 місце в загальному рейтингу (табл. 2). Варто відзначити перше місце за кількістю заявок на корисні моделі та 19-те місце за кількістю патентних заявок на винаходи, що подані за національною системою. Разом з тим, за показником надходження від інтелектуальної власності Україна посідає лише 50-те місце в рейтингу. Також Україна посіла 15-те місце в 2018 році за експортом IT-послуг.

Таблиця 2 - Складові показника «6. Результати знань і технологій» України Глобального індексу інновацій у 2018 році

\begin{tabular}{|c|c|c|}
\hline Показник & Оцінка & Місце \\
\hline 6.1. Створення знань & 46,8 & 15 \\
\hline 6.1.1. Патентні заявки, подані в національні агентства інтелектуальної власності & 6,3 & 19 \\
\hline 6.1.2. Міжнародні патентні заявки, подані за системою РСТ & 0,4 & 38 \\
\hline 6.1.3. Заявки на корисні моделі, подані в національні агентства інтелектуальної власності & 26,8 & 1 \\
\hline 6.1.4. Науково-технічні статті, які індексуються базою Web of Science & 10,2 & 50 \\
\hline 6.1.5. Н-індекс публікацій & 15,0 & 49 \\
\hline 6.2. Вплив знань & 42,0 & 40 \\
\hline 6.2.1. Зростання ВВП на 1 працюючого & 3,4 & 15 \\
\hline 6.2.2. Нові підприємства & 1,5 & 60 \\
\hline 6.2.3. Витрати на програмне забезпечення & 0,6 & 17 \\
\hline 6.2.4. Сертифікати якості ISO 9001 & 3,9 & 71 \\
\hline 6.2.5. Високотехнологічна та середньотехнологічна продукція & 0,2 & 50 \\
\hline 6.3. Поширення знань & 21,3 & 53 \\
\hline 6.3.1. Надходження від інтелектуальної власності & 0,2 & 46 \\
\hline 6.3.2. Експорт високотехнологічної продукції & 3,1 & 45 \\
\hline 6.3.3. Експорт IT-послуг & 4,8 & 15 \\
\hline 6.3.4. Чистий відтік прямий іноземних інвестицій & 0,2 & 92 \\
\hline
\end{tabular}

Джерело: побудовано на основі даних Глобального інноваційного індексу (2018)

Крім цього, необхідно відзначити значні показники людського капіталу за охопленням вищою освітою (12-те місце), співвідношення кількості учнів до кількості вчителів у середній школі (3-те місце), кількістю заявок на торгові марки та промислові зразки (5 та 7-ме місця відповідно) тощо.

Також спробуємо оцінити стан інформатизації України в цілому. Для цього використаємо Індекс мережної готовності.

Індекс мережної готовності Всесвітнього економічного форуму (Networked Readiness Index - NRI) вимірює здатність країн використовувати можливості, які пропонують IT-технології. У 2016 році NRI містить чотири компоненти: навколишнє середовище для IT-технологій, які пропонуються країною чи суспільством, готовність ключових зацікавлених осіб (інфраструктура, доступність, навички) до використання ІТ-технологій, використання IT-технологій серед цих зацікавлених осіб та фактори впливу (економічні та соціальні). Україна в цьому списку 2016 року займає 64 місце, поступаючись Монголії (59 місце), Грузії (58 місце), Польщі (42 місце) та Казахстану (39 місце). Російська Федерація знаходиться на 77-му місці.

Показники за кожною складовою рейтингу 2016 року для України наведені в табл. 3. 
Таблиця 3 - Складові рейтингу 2016 мережної готовності України

\begin{tabular}{|l|l|l|}
\hline \multicolumn{1}{|c|}{ Складова } & \multicolumn{1}{|c|}{ Оісце } & Оцінка \\
\hline Оточення & 94 & $\mathbf{3 , 8}$ \\
\hline - політичне та регуляторне & 113 & 3,2 \\
\hline - бізнес та інфраструктура & 67 & 4,3 \\
\hline Готовність & 30 & $\mathbf{5 , 7}$ \\
\hline - інфраструктура & 51 & 4,7 \\
\hline - доступність & 6 & 6,6 \\
\hline - навички & 33 & 5,6 \\
\hline Користування & $\mathbf{8 8}$ & $\mathbf{3 , 6}$ \\
\hline - індивідуальне & 76 & 3,9 \\
\hline - бізнесу & 63 & 3,6 \\
\hline - урядових структур & 114 & 3,1 \\
\hline Вплив & 69 & $\mathbf{3 , 7}$ \\
\hline - економічні чинники & 59 & 3,4 \\
\hline - соціальні чинники & 75 & 4,0 \\
\hline Загальний рейтинг & 64 & $\mathbf{4 , 2}$ \\
\hline \multicolumn{2}{|l}{ Джерело: побудовано на основі даних Індексу мережевої готовності (2016) } & \\
\hline
\end{tabular}

Як видно з табл. 3 Україна має досить високі показники за доступністю IT-технологій - 3 місце. Цей показник досягається завдяки одним з найдешевших тарифів на Інтернет (2 місце у світі), тоді як інші складові цього показника мають гірші значення: 48 місце за тарифи на мобільний зв'язок та 80 місце за рівень конкуренції у сфері інтернету та телефонії.

Як і в попередньому рейтингу інновацій слабкою стороною України є політичне та регуляторне середовище (113 місце): ефективність законодавчої гілки влади - на 120 місці, незалежність судової системи - на 131, захисті інтелектуальної власності - на 120 місці.

Вважаючи тему дослідження проаналізуємо також користування IT-технологіями в бізнесі. Рівень поглинання технологій на рівні бізнесу оцінюється у 4,2 бали з 7, а це 100 місце серед 139 країн. Використання ІТ-технологій у В2В сфрері - 4,4 бали за аналогічною шкалою або 89 місце, ступінь підготовки персоналу - 3,9 бали або 74 місце. Вплив IT-технологій на моделі бізнесу в Україні сягає 113 місця. Також досить низький рівень розуміння важливості ІТ-технологій у владних структурах - 122 місце.

Варто відзначити, що в 2015 році Україна займала 71е місце, тобто піднялася в рейтингу на 9 пунктів.

3 огляду на дані отримані 3 аналізу вищеназваних рейтингів додатково потребує вивчення рівень корупції в Україні.

Рейтинг рівня корумпованості розраховується різними організаціями, найбільш відома з яких - міжнародна організація Transparency International. Індекс сприйняття корупції розраховують на основі 13 досліджень авторитетних міжнародних установ і дослідницьких центрів. Для визначення оцінки України використано 9 джерел. Ключовим показником Індексу $€$ кількість балів, а не місце в рейтингу. Мінімальна оцінка (0 балів) означає, що корупція фактично підміняє собою державу, максимальна (100 балів) свідчить про те, що корупція майже відсутня в житті суспільства. Індекс оцінює корупцію лише в державному секторі (Індекс сприйняття корупції,
2018).

У 2018 році Україна опинилася на 120 місці серед 180 країн з оцінкою 32 бали. У 2017 році Україна посідала 130 місце з Зобалами балами, що все одно відноситься до країн із загрозливим рівнем корупції.

Хоча за останні роки в Україні відбувається певні зрушення, що направленні на боротьбу з корупцією (автоматичне відшкодування податку на додану вартість, регулярна робота інституту бізнес-омбудсмена, функціонування електронних систем ProZorro). Проте в той же час рівень недовіри до судової гілки влади як з боку фізичних, так і юридичних осіб досить високий. Також останніми роками в Україні відбулися серії нападів на журналістів та активістів, які вели свою діяльність у сфрері протидії корупції (Індекс сприйняття корупції, 2018).

Показники індексу сприйнятті корупції серед сусідів України в 2018 році: Польща - 60, Румунія - 47, Угорщина 46, Білорусь - 44, Молдова - 33.

Такі умови не сприяють для розвитку підприємництва, впровадження інноваційних технологій, стабільній взаємодії із зовнішнім середовищем як всередині країни, так і за її межами.

Проведений аналіз різних міжнародних рейтингів оцінювання різних сфер діяльності України дає змогу виділити проблеми, з якими може зіштовхнутися вітчизняне підприємство в процесі впровадження маркетингового тестування інноваційної продукції.

Розглянемо основні з них. Вплив зовнішніх (держава, конкуренти, економічні контрагенти) та внутрішніх фракторів (персонал та організаційна структура і бізнес-процеси) на процес впровадження маркетингового тестування на різних етапах інноваційного циклу розроблення продукції наведений на рис. 1.

Більш детально проблеми впровадження маркетингового тестування інноваційної продукції на вітчизняних підприємствах описані нижче. 


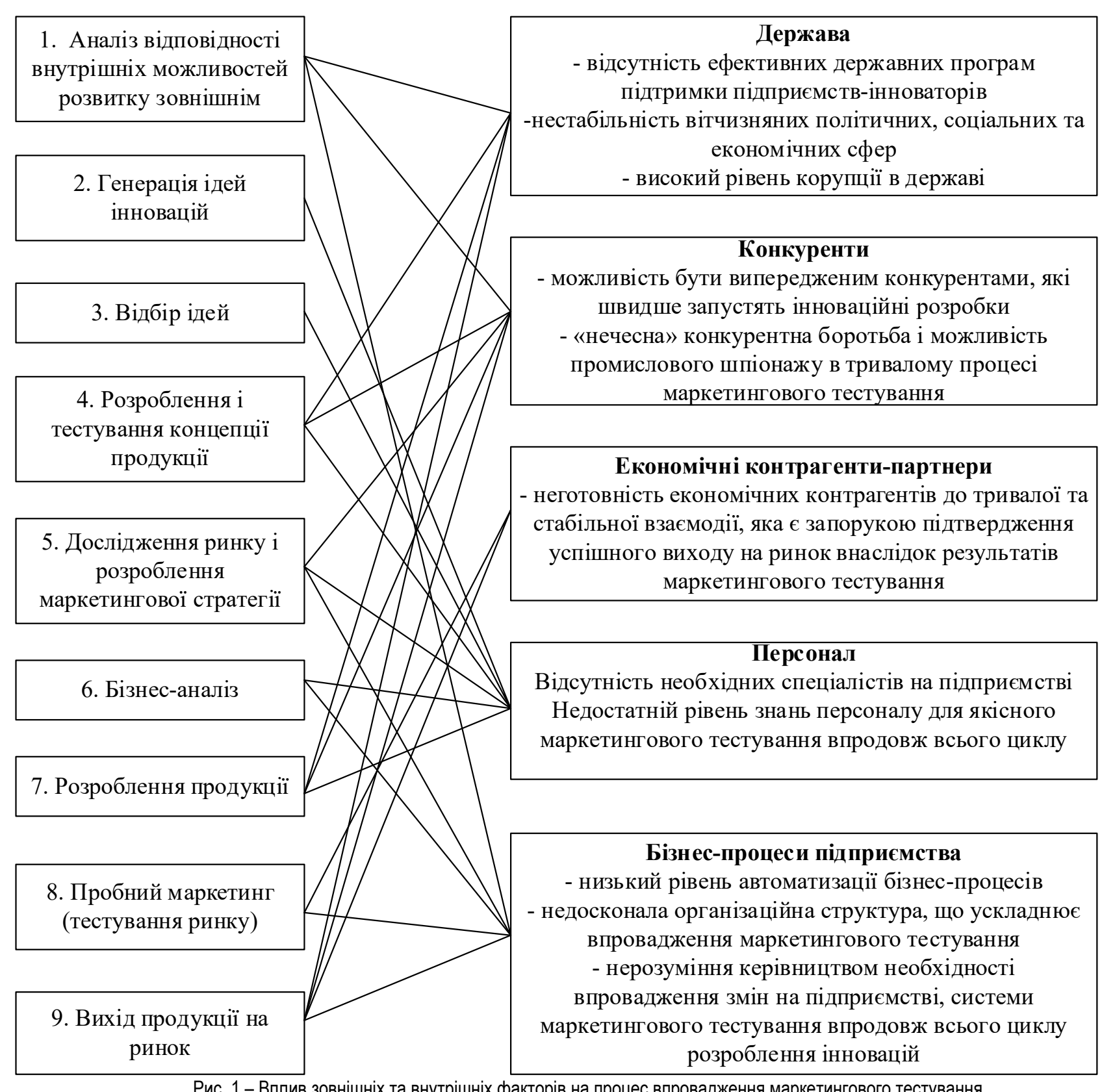

Рис. 1 - Вплив зовнішніх та внутрішніх факторів на процес впровадження маркетингового тестування на різних етапах інноваційного циклу розроблення продукції

1. Зовнішне середовище:

- високий рівень корупції та тіньового бізнесу стримує розвиток вітчизняних підприємств та перешкоджає цивілізованій системі взаємодії із зовнішнім середовищем як всередині країни, так і за її межами;

- відсутність ефективних державних програм підтримки підприємств-інноваторів та справедливої і прозорої системи оцінювання в процесі відбору для державного фінансування;

- низький рівень дотримання ділового етикету серед вітчизняних підприємств $€$ наслідком зазначеного у попередньому пункті та бажанням керівництва підприємств отримувати якомога більші прибутки хоч і нелегальними та обманними способами;

- неготовність економічних контрагентів до тривалої та стабільної взаємодії, яка крім переваг для самого підприємства у вигляді збільшення прибутків і зменшення витрат у майбутньому, надає обов'язки з дотримання ділового етикету, домовленостей та певних умов співпраці;

- недосконалість українського законодавства у сфері господарської діяльності, інтелектуальної власності, інформаційних питань. Відсутність чітких норм у цих сферах або відсутність покарання за недотримання існуючих законодавчих актів робить призводить до недобросовісної конкуренції та беззахисності підприємства проти протиправних дій інших економічних контрагентів;

- нестабільність політичної, соціальної та економічної сфрер української економіки, що призводить до ускладнення прогнозування та адаптації умов маркетингового тестування до умов реального виробництва та розповсюдження продукціï.

2. Внутрішнє середовище:

- небажання та неготовність працівників переходити до нової концепції управління, змінювати існуючі принципи 
роботи. Ця проблема виникає через низькі рівні заробітної плати та економічної освіченості персоналу;

- нерозуміння керівництвом необхідності змін та впровадження маркетингового тестування впродовж всього циклу розроблення інноваційної продукції на своєму підприємстві через низький рівень економічної освіченості, нерозуміння економічних процесів та необхідності налаштування на тривалу та стабільну діяльність;

- недосконалість організаційної структури для впровадження системи маркетингового тестування. Формування чи рефрормування організаційної структури може відбуватися хаотично, без глибокого аналізу цілей та завдань організаційної структури, специфіки підприємства;

- недосконалість і дублювання існуючих або відсутність необхідних бізнес-процесів для впровадження маркетингового тестування впродовж всього циклу розроблення інноваційної продукції, основується на неправильно сформованій організаційній структурі;
- неавтоматизованість бізнес-процесів через відсутність достатньої кількості комп'ютерної техніки та програмного забезпечення, їхню високу вартість та низький рівень комп'ютерної освіченості персоналу;

- небажання керівництва вкладати кошти в комп'ютерну техніку та програмне забезпечення;

- застарілість організації бізнес-процесів на підприємстві через відсутність контролінгу діяльності та аналізу її ефективності.

Висновки. Таким чином, проаналізувавши місце та показники України в рейтингах країн у сферах інновацій, інформатизації та державного управління було виділено основні проблеми, з якими можуть зіштовхнутися вітчизняні підприємства в процесі впровадження маркетингового тестування на різних етапах розроблення інноваційної продукції. Подальші дослідження будуть направлені на пошук шляхів подолання цих проблем та удосконалення методологічних засад маркетингового тестування інноваційної продукції.

\section{Список літератури:}

1. Corruption Perception Index 2018. (2018). Retrieved from http://cpi.ti-ukraine.org.

2. Pysarenko, T.V., \& Kvasha, T.K. (2018). Stan innovatsiinoi diialnosti ta diialnosti u sferi transferu tekhnolohii v Ukraini u 2017 rotsi: analitychna dovidka [State of Innovation and Technology Transfer Activity in Ukraine in 2017: Analytical Reference]. Kyiv: UkrISTEI.

3. Teletov, O.S., Ivashova, N.V., \& Nahornyi, Y.I. (2013). Innovatsii v marketynhu promyslovoho pidpryiemstva [Innovation in the marketing of industrial enterprise]. Sumy: Sumy State University.

4. Cornell University, INSEAD, \& WIPO (2018). The Global Innovation Index 2018: Energizing the World with Innovation. Ithaca, Fontainebleau, and Geneva. Retrieved from https://www.wipo.int/publications/en/details.jsp?id=4330.

5. Baller, S., Dutta, S., \& Lanvin, B. (Eds.). (2016). Global Information Technology Report 2016. Innovating in the Digital Economy . Geneva : World Economic Forum. Retrieved from http://reports.weforum.org/global-information-technology-report-2016.

6. Networked Readiness Index. (n.d.). Retrieved from http://reports.weforum.org/global-information-technology-report2016/networked-readiness-index/.

7. The Global Innovation Index. (n.d.). Retrieved from https://www.globalinnovationindex.org/.

8. Transparency International. (n.d.). Retrieved from https://www.transparency.org.

9. Ukraine in the Global Innovation Dimension Report 2007-2017. (2018). Retrieved from https://unitcitizen.com/wp-content/uploads/2018/05/UReport_final-version_1.pdf.

Golysheva I.O., PhD, Associate Professor, Sumy National Agrarian University (Sumy, Ukraine)

Analysis of the external and internal factors influence on implementation the process of innovation marketing testing

It is analyzed the place and indicators of Ukraine in the ratings of different spheres: innovation, information and public administration. The following ratings were used in the research: Networked Readiness Index, The Global Innovation Index and Corruption Perception Index. Independent evaluation of international organizations made it possible to highlight the strengths and weaknesses of the Ukrainian economy. The main problems of Ukraine are unstable political and regulatory spheres, distrust of ship and legislative systems, high level of corruption, low level of business automation. The strengths of Ukraine include human capital both in the field of science and intellectual property, and in the IT sphere. Based on this it is identified the problems that may arise in domestic enterprises in the implementing process of innovation marketing testing.

Marketing testing is proposed to be introduced not only at the final stages of innovation development, but throughout the entire cycle from analyzing of the internal and external capabilities of the enterprise to launching the product on the market. Therefore, external (state, competitors, economic players) and internal (staff, management, business processes, organizational structure) factors that affect marketing testing depending on the stage of the innovation development cycle were also identified.

Keywords: innovation, informatization, corruption, innovation cycle.

Дата надходження до редакції: 17.01.2019 р. 